\title{
A dessacralização das ciências sociais da religião no Brasil nas trilhas de Weber, Bourdieu e Pierucci
}

Renan William dos Santos*

https://orcid.org/0000-0003-4490-6536

Introdução

Em $O$ ofício do sociólogo (2007), Pierre Bourdieu descreve uma série de atitudes epistemológicas que se fazem necessárias à realização da análise científica no campo da sociologia. Duas delas mostraram-se excepcionalmente pertinentes no quinhão acadêmico voltado à pesquisa das religióes, sobretudo por serem frequentemente ignoradas: (1) afastar-se analiticamente em relação ao objeto pesquisado (Bourdieu, 2007, p. 23); e (2) "nunca recorrer a explicações substancialistas" (Idem, pp. 30-31).

Comecemos pela primeira advertência, a de que a apreensão de um fenômeno depende de um "passo atrás", de um afastamento do pesquisador em relação ao seu objeto. Uma vez que as ciências sociais costumam abordar fenômenos presentes no cotidiano do próprio pesquisador, "a familiaridade com o universo social constitui, para o sociólogo, o obstáculo epistemológico por excelência” (Bourdieu 2007, p. 23). Ou seja, diferentemente do físico com seu laboratório, não há, entre nós, distinção clara entre pesquisador e objeto.

Essa falta de distanciamento é particularmente problemática nos estudos sobre a religião. A dificuldade, nesse caso, não está na fé em si, mas nos diversos "interesses religiosos" que podem, direta ou indiretamente, influenciar as análises. Isto é, podem entrar em cena interesses em ressaltar ou obscurecer, em exaltar ou criticar

* Universidade de São Paulo, São Paulo, Brasil. 
aspectos da realidade estudada que estão diretamente ligados à própria identidade e à posição social do pesquisador (Bourdieu, 1990b, pp. 109-110). Ocorre que, em vez de isso ser controlado ${ }^{1}$ em razão das distorções que pode gerar, muitas vezes a pertença identitária ao campo estudado é considerada um trunfo: "aqueles que a ele pertencem tendem a fazer dessa pertença condição necessária e suficiente para o conhecimento adequado" (Bourdieu, 1990b, p. 110).

Bourdieu reconhece que há uma "parcela de verdade" na exaltação do conhecimento interno, na medida em que a pertença permite o acesso a certas facetas e detalhes que passam despercebidos a quem não os vivencia. Porém, do ponto de vista do interesse científico, que não é o interesse complacente de primeiro grau, o "tesouro autóctone" e as "pequenas bobagens" que assumem importância apenas àqueles que estão envolvidos no jogo em questão precisam necessariamente ser descartados em favor de uma perspectiva mais ampla - e aqui vale a velha metáfora de que é preciso se afastar das árvores para ver melhor a floresta (Bourdieu, 1990b, p. 110).

Para que o afastamento ocorra, a análise sociológica deve se assumir necessariamente como "mundana”, isto é, não apologética, secularizada, desencantada, mesmo que (aliás, sobretudo quando) o fenômeno em questão seja a religião. Na medida em que se pretenda fazer uma análise científica, não há outro caminho. Obviamente, de forma alguma esse afastamento deve redundar em uma análise depreciativa, desdenhosa ou reducionista, por mais dessacralizante que seja qualquer prática científica ${ }^{2}$.

$\mathrm{Na}$ análise dos fenômenos religiosos, a primeira advertência epistemológica de Bourdieu leva à segunda, porque, como as questões da fé parecem contornar considerações racionais e interesses "profanos", é comum que se recorra, para explicá-las, a raciocínios substancialistas, como os que falam em aspirações, tendências e inclinações naturais presentes nos seres humanos (Bourdieu, 2007, pp. 30-1). Trata-se, para análise científica, de demonstrar justamente o contrário, isto é, evidenciar como essas aspirações, tendências e inclinações são não só socialmente determinadas como, em seguida, naturalizadas, garantindo assim sua reprodução.

1. Uma vez que é grande o número daqueles que, seja nos estudos da religião ou nas demais áreas, pesquisam temas ligados à própria identidade, convém esclarecer desde já: Bourdieu aponta que o controle, isto é, uma “objetivação da participação", é perfeitamente possível. Ou seja, não se está excluindo, de forma alguma, a possibilidade de um bispo católico, por exemplo, produzir uma excelente sociologia do catolicismo. Tudo depende da recusa em "jogar o jogo duplo social e psicologicamente vantajoso que permite acumular as vantagens da cientificidade (aparente) e da religiosidade" (Bourdieu, 1990b, p. 112).

2. Um dos maiores nomes das ciências sociais da religião, Peter Berger, que é assumidamente integrante do campo religioso enquanto teólogo luterano, já disse certa vez que qualquer pesquisa científica sobre assuntos religiosos, mesmo que praticada por um fiel, "tem necessariamente que estar baseada num ateísmo metodológico" (1985, p. 112, grifos no original). O mesmo é expresso por James Beckford, substituindo, porém, ateísmo por "agnosticismo metodológico" (Beckford, 2008, p. 29, tradução minha). 
Para tanto, é imprescindível se valer de um olhar teoricamente informado, que distinga o fenômeno em sua apresentação espontânea (tal como é apreendido e descrito pelos próprios agentes envolvidos) de sua apresentação como objeto de pesquisa que precisa ser compreendido, mais do que apreendido (Bourdieu, 2007, p. 46). Nesse sentido, não apenas o senso comum, mas uma postura científica vulgarmente empirista também se mostra problemática, pois “o real nunca toma a iniciativa, já que só dá resposta quando é questionado" (Bourdieu, 2007, p. 48). As estatísticas e correlações encontradas a partir da empiria, por exemplo, não são autoexplicativas, ao mesmo tempo que não tem sentido fazer sínteses teóricas autônomas em relação à observação das coisas. É preciso, pois, adotar um caminho do meio, mantendo o interesse pela realidade, mas não ingênuo, como se a explicação da realidade estivesse nas coisas. Só assim se chegará aos determinantes, aos condicionamentos e às relações que estão subjacentes aos fatos sociais que se apresentam como simples manifestações empíricas espontâneas.

Esse é, aliás, um dos grandes "incômodos" causados pela sociologia, que aponta "o arbitrário, a contingência, ali onde as pessoas gostam de ver a necessidade ou a natureza [...] e que descobre a necessidade, a coação social, ali onde se gostaria de ver a escolha, o livre arbítrio" (Bourdieu, 1990a, p. 27). Para citar aquele que também será discutido aqui como inspiração da sociologia da religião bourdieusiana, Max Weber: "nossa ciência tem justamente por vocação dizer o que ninguém gosta de ouvir" (Weber, 2014a, p. 31). A desnaturalização que o raciocínio sociológico opera na compreensão dos fenômenos religiosos pode ser vista, por exemplo, na ideia de que a formulação e a emissão das pregações não teriam qualquer eficácia simbólica sem um prévio "trabalho religioso" (o catecismo, por exemplo) que desse o aporte necessário à sua decodificação e aplicação cotidiana (Bourdieu, 2002, p. 50, nota 59). Aliás, desse ponto de vista "mundano", que rejeita a religião como característica inata da condição humana, não só a compreensão das mensagens religiosas, mas a própria "experiência dos 'seres' sobrenaturais da religião [...] também supõe disposições adquiridas" (Bourdieu, 2001, p. 138).

Em suma, apesar de a religião não ter um lugar privilegiado ${ }^{3}$ na obra de Bourdieu, são vários os insights por ele fornecidos seja diretamente, por meio de seus textos que tratam do assunto, seja indiretamente, através de raciocínios sociológicos desenvolvidos para tratar de outros fenômenos. Pensando-se nas duas advertências epistemológicas abordadas até aqui, um pesquisador em especial, Antônio Flávio de

3. Erwan Dianteill lança a interessante tese de que Bourdieu não se deteve de forma mais aprofundada no estudo do fenômeno religioso em específico por considerar que a religião, sobretudo aquela institucionalizada, representada na França pela Igreja Católica, seria uma força social em declínio, fadada a ocupar um papel marginal nas sociedades modernas (Dianteill, 2003, p. 41). 
Oliveira Pierucci ${ }^{4}$, foi responsável por propalar as implicações de sua não observância no estudo da religião no contexto brasileiro. Apesar de estudiosos da religião no Brasil já terem usado algo do arsenal teórico bourdieusiano poucas décadas antes ${ }^{5}$, muito da crítica às crenças dos sociólogos da crença, por exemplo, foi introduzida e mediada no contexto nacional pelo uso que Pierucci fez de Bourdieu. Assim, é acompanhando as análises e polêmicas suscitadas e levadas a cabo por Pierucci que se pretende explicitar, aqui, ao menos uma parcela das repercussões que a obra de Bourdieu teve nas ciências sociais da religião no Brasil.

Weber apud Bourdieu: balizas de uma análise mundana do campo religioso

\begin{abstract}
Naquele meu primeiro ano de vida no Cebrap [1971], chegou à nossa biblioteca um fascículo da revista Archives Européennes de Sociologie [...]. O artigo sobre Weber era assinado por um tal de Pierre Bourdieu, de quem ninguém naquela casa tinha me falado antes. [...] [N]esse escrito Bourdieu faz o grande favor de evidenciar em Weber o que este mesmo evidencia com sua Sociologia da Religião, a saber: o trabalho religioso realizado pelos profissionais da religião. Primeira "verdade sociológica" que ele me levou a captar como o neófito que eu era em Sociologia da Religião: não há religião sem que haja (antes e consecutivamente) o trabalho religioso do profissional da religião. Bingo! (Pierucci, 2006, grifos meus).
\end{abstract}

Pelo que se pode perceber nesse relato de Pierucci, é como uma espécie de "comentador" de Weber que Bourdieu desembarca na sociologia da religião brasileira. Até então, mesmo num centro de pesquisas como o Cebrap, que sempre se destacou em termos de internacionalização, o nome de Bourdieu era pouco conhecido - não só nos estudos sobre a religião, mas também em outras áreas. Em grande parte, isso se deve ao fato de que "na década de 1970 são poucos os textos disponíveis e raros os autores brasileiros que o utilizam no âmbito das ciências sociais” (Ortiz, 2013, p. 82). E assim continuaria até meados dos anos 1990, quando sua obra passa a ser mais difundida no Brasil (Bortoluci et al., 2015, p. 244).

4. Pierucci aparece, em qualquer balanço bibliográfico da área, ou mesmo em textos críticos às suas análises, como um dos mais destacados sociólogos da religião no Brasil (Herrera, 2004; Mariano, 2013; Camurça, 2001). Ele produziu volumosa obra composta por "mais de cinquenta artigos publicados em renomados periódicos do Brasil e afora, seis livros (sem contar as reedições), dezenas de verbetes em enciclopédias, mais de trinta capítulos de livros, além de toda uma série de artigos em jornais e revistas como Folha de S.Paulo, Estado de S. Paulo, Ciência Hoje, entre outros" (Bonato et al., 2016, p. 13).

5. Pode-se mencionar aqui, entre esses pioneiros, Duglas Teixeira Monteiro e seu então orientando Carlos Rodrigues Brandão, que se valeram, ainda na década de 1970, da recém-criada noção de gênese e estrutura do campo religioso (Herrera, 2004, pp. 128-129). 
Ora, é justamente na década de 1990 que Pierucci propôs a perspectiva bourdieusiana como ponto consensual possível: "um pouco mais de Bourdieu, do modo como Bourdieu olha a religião, um pouco mais daquele rigor científico radicalmente desencantado que disseca o objeto enquanto critica a própria disciplina que o indaga, faria muito bem a todos nós" (Pierucci, 1997, p. 251).

Esse modo "desencantado" de olhar a religião, segundo Pierucci (2003), Bourdieu buscou em Weber. A intenção neste tópico é justamente explicitar algumas dessas aproximações ${ }^{6}$ entre as leituras "desencantadas" que Bourdieu e Weber fazem da religião, para depois, seguindo a proposta de Pierucci, explorar seu potencial de instrumentalização na análise da dinâmica contemporânea do contexto religioso brasileiro. Isso posto, voltemos ao ponto crucial da convergência:

Bourdieu chama a atenção para o fato de que Weber, no texto sobre Sociologia da Religião de Economia e sociedade, "coloca de chofre que as ações mágicas ou religiosas são mundanas em seu princípio e devem ser realizadas 'para se ter uma vida longa'” (Bourdieu, [2011a], p. 32). "De chofre", diz Bourdieu, e é assim mesmo; Bourdieu notou corretamente esse gesto de Weber, que logo de cara introduz esse seu poderoso insight sociológico, quase tão materialista-histórico quanto um enunciado marxiano tirado do núcleo d' $A$ ideologia alemã, e que o editor põe em destaque no frontispício [...]: "A primordial mundanidade da ação comunitária motivada religiosa ou magicamente” (Pierucci, 2003, p. 83, grifos no original).

Conforme a pertinente observação de Erwan Dianteill, “a obra de Bourdieu é quase uma sociologia das religiões 'generalizada', na qual a religião apresenta, de modo paradigmático, propriedades comuns a todas as esferas de atividade simbólica” (Dianteill, 2003, p. 30). Isso se deve ao fato de que, apesar de a religião não ter sido um tema central em sua obra, vários dos conceitos utilizados por Bourdieu originaram-se de uma leitura crítica de trabalhos oriundos da sociologia da religião ${ }^{7}$. As inspirações, obviamente, não partiram apenas de Weber. Bourdieu trouxe de Émile Durkheim e Marcel Mauss, por exemplo, a compreensão de que a religião elabora ferramentas de percepção e classificação do mundo. Já de Karl Marx - além da noção de capital (não restrita ao aspecto material) -, Bourdieu

6. Existem também muitas divergências. Lísias Negrão, por exemplo, pontua que "embora partindo de Weber, Bourdieu dele se distancia em um ponto essencial: na avaliação do papel da intersubjetividade na mudança histórica” (Negrão, 2005, p. 25). Pierucci e Negrão também têm discrepâncias profundas acerca do uso do conceito weberiano de "desencantamento do mundo" para descrever o contexto brasileiro, conforme será discutido mais à frente.

7. Para um detalhamento das obras e trechos nos quais o próprio Bourdieu credita alguns de seus conceitos e inspirações às análises provenientes da sociologia da religião, ver Arribas (2012). 
conservou a concepção de que a religião comporta uma função mistificadora, que atua na reprodução da ordem social ${ }^{8}$.

É, porém, partindo de Max Weber - em suas próprias palavras, ao mesmo tempo "com" e "contra Weber" - que Bourdieu elaborou a noção de campo enquanto recorte social relativamente autônomo e povoado por agentes específicos em disputa para impor tais ou quais práticas e concepções como legítimas (Bourdieu, 1990e, p. 66, grifos no original). Na fundamentação da teoria dos campos, que ocupa o "centro" da sociologia bourdieusiana da religião (Dianteill, 2003, p. 39), está a constatação de que o mundo social moderno passou por uma diferenciação progressiva que deu origem a diversos campos com autonomia relativa: o da economia, da arte, da ciência, da religião etc. (Bourdieu, 2008a, p. 147).

É aí que aparece, segundo Bourdieu, o maior mérito de Weber: fornecer uma chave sociológica para escapar, nas análises dos fenômenos da esfera religiosa (e também das demais), da ilusão de autonomia absoluta e, ao mesmo tempo, da teoria reducionista às condições materiais. $\mathrm{O}$ caminho analítico de Weber "consiste em chamar atenção sobre os produtores desses produtos particulares (no caso que mais o interessa, os agentes religiosos) e sobre suas interações (conflito, concorrência etc.)" (Bourdieu, 2001, p. 215). O processo histórico que levou ao monoteísmo, por exemplo, só pôde realizar-se, segundo Weber ([1922] 2004, p. 292), por meio da acomodação de "poderosos interesses ideais e materiais dos sacerdotes interessados nos cultos e nos lugares de culto dos deuses particulares”. Nesse caso, encontrou-se um ajustamento na organização hierarquizada do sacerdócio, ou seja, uma divisão do trabalho religioso (Bourdieu, 2011b, p. 85).

Ao fazer esse movimento, "Weber estende a análise econômica (no sentido generalizado) às áreas geralmente ignoradas pela economia, como a religião”, praticando, assim, uma forma de "materialismo radical que busca os determinantes econômicos (no sentido mais amplo) em áreas onde reina a ideologia do 'desinteresse”" (Bourdieu, 1983, p. 20, grifos meus). É justamente nesse sentido, e apenas nesse, que Pierucci afirma que "nunca se é excessivamente materialista quando o que se pretende honestamente fazer é, com todas as letras e todas as exigências epistemológicas e implicações deontológicas, sociologia da religião" (Pierucci, 2003, p. 84).

8. Para Bourdieu, essa "função política" exercida pela religião, isto é, a "alquimia ideológica pela qual se opera a transfiguração das relações sociais em relações sobrenaturais” (Bourdieu, 2011a, p. 33), não pode ser ingenuamente assumida como autônoma e a teoria marxista é essencial nessa desmitificação. Contudo, o discurso religioso e os interesses que ele defende, diz Bourdieu, também não podem ser considerados como "reflexo direto das estruturas sociais" (Idem, p. 32). A chave para escapar dessa antinomia, conforme será discutido mais à frente, é a noção de "trabalho religioso" (Idem, p. 33). 
É a Weber, portanto, que Bourdieu atribui a ideia de correlacionar "o conteúdo do discurso mítico (inclusive sua sintaxe) aos interesses religiosos daqueles que o produzem, que o difundem e que o recebem" (Bourdieu, 2011a, p. 32). Essa correlação é profundamente "dessacralizante" na medida em que, a partir dela, mesmo as ações mais "santas" e aparentemente desinteressadas serão explicadas como oriundas da "busca do lucro simbólico da santidade" (Bourdieu, 2008a, p. 150). Aos ouvidos religiosamente afinados, tal dessacralização pode soar, isto sim, como profanação. Contudo, como já antecipava Weber em seu prólogo aos Ensaios reunidos de Sociologia da Religião, "quem deseja 'sermões' que vá a um convento" (Weber, [1906] 1920).

Vale ressaltar, porém, que a perspectiva dessacralizante delineada por Weber e desenvolvida por Bourdieu não pressupõe que os agentes sejam hipócritas, mentirosos ou algo do tipo. A noção de habitus é especialmente relevante nesse sentido, pois permite pensar que as condutas sejam "orientadas em relação a determinados fins sem ser conscientemente dirigidas a esses fins" (Bourdieu, 1990a, p. 22), já que derivam de um "senso prático", do conhecimento tácito das regras de um jogo social particular (Bourdieu, 1990d, pp. 81-83).

\section{Bourdieu apud Pierucci: as ciências sociais da religião no Brasil no purgatório}

Para grande parte dos cientistas sociais que estudam religião no Brasil existe uma especial dificuldade de decidir até onde, em seu trabalho intelectual, vai a ciência e até onde vem a religião, dificuldade séria de demarcar o contraste com a não ciência, de se demarcar reflexivamente sabendo onde começa uma e onde termina a outra (Pierucci, 1999, p. 237).

É o que diz Pierucci já "de cara”, no primeiro parágrafo de um de seus mais controversos textos, "Sociologia da religião: área impuramente acadêmica" (1999), que integra a coletânea O que ler na ciência social brasileira (1970-1995), organizada por Sergio Miceli ${ }^{10}$. O texto originou-se da sistematização e aprofundamento de considerações tecidas alguns anos antes, em 1996, na conferência Interesses religiosos dos sociólogos da religião, apresentada na vi Jornadas sobre Alternativas Religiosas na América Latina ${ }^{11}$. Tais provocações, que tiveram lugar naquele que é talvez o mais importante

9. Conhecido também como "Introdução do autor", esse prólogo costuma ser erroneamente entendido como uma introdução à $A$ "ética" protestante e o "espirito" do capitalismo (Weber, [1920] 2014b).

10. A menção ao organizador aqui não é sem propósito. Miceli é, reconhecidamente, um dos responsáveis pela introdução e divulgação da obra de Bourdieu no Brasil (Bortoluci et al., 2015, pp. 226-227). É icônico, portanto, que Pierucci tenha escolhido justamente essa coletânea para desembainhar o arsenal bourdieusiano e ir à carga contra aquilo que considerava problemático em sua área de pesquisa.

11. Um trecho do memorial do concurso de titular de Pierucci mostra quão silenciada era essa questão no campo dos estudos da religião até então: "Aproveitei minha primeira participação nas chamadas 
congresso de ciências sociais da religião na América Latina, foram posteriormente publicadas numa coletânea ${ }^{12}$ de Ari Oro e Carlos Steil (1997).

Como narra Ricardo Mariano numa breve biografia cujo título é Antônio Flávio Pierucci: sociólogo materialista ${ }^{13}$ da religião, desde essa conferência nas Jornadas - e até seus últimos textos, antes de falecer, em 2012 - Pierucci assumiu como nenhum outro no campo acadêmico brasileiro a polêmica tarefa de "alertar os cientistas sociais da religião sobre as eventuais armadilhas do excesso de 'boa vontade cultural' com as (ou de pura ingenuidade em relação a) instituições religiosas dotadas de poderes políticos, midiáticos e econômicos" (Mariano, 2013, p. 15).

O próprio Pierucci deixou claro o que, de início, ainda na década de 1990, o motivou a passar adiante o "recado" de Bourdieu a respeito dos problemas causados pela existência de interesses religiosos entre aqueles que se propunham a estudar cientificamente a religião:

[...] acho que devo, sim, esclarecer os motivos que me levaram a querer passar adiante este "recado" [de Bourdieu]. É que anda muito na moda, agora, fazer sociologia da religião para elogiar a religião, mostrar os benefícios que ela faz às pessoas, sobretudo se das camadas despossuídas, à sociedade como um todo, à própria democracia. Hoje não é raro, muito pelo contrário, é cada vez mais frequente ouvir de "sociólogos da religião" (sem fé ou sem cerimônia?) que a religião confere empowerment às pessoas porque fortalece o associativismo voluntário, que a religião aumenta a autoestima dos indivíduos das camadas mais desprotegidas porque os motiva a abandonar comportamentos indesejáveis, como o alcoolismo, o homossexualismo, a dependência de drogas etc. (só falta falar que a religião liberta os pobres

'Jornadas' para fazer minha primeira crítica ao vivo e em cores aos 'sociólogos religiosos da religião'. Foi também a primeira vez, tenho certeza, que meus colegas de área ouviram essa nomenclatura assim tão carregada de intenções polêmicas [...]. Eu passaria desde então a ser olhado, se não ouvido, com outro interesse (para dizer o mínimo) pelos cientistas sociais da religião do Brasil e do Cone Sul, alguns deles já começando a me chamar, pelas costas, de "palmatória do mundo", enquanto outros se achegavam para confessar concordância com meu ponto de vista. Segundo esses, com minha coragem (sic) eu dera início a uma discussão metateórica que afinal de contas precisava mesmo ser feita mais dia menos dia, a fim de resgatar "a área" de sua rotinizada ingenuidade empirista. De sua falta de autocrítica, em suma. Era como se eu tivesse vindo quebrar um longo silêncio. Senti-me desmontando, numa dedada certeira, todo um castelo de cartas de ilusão profissional e inocência metateórica, ambas sem mais cabimento àquela altura" (Pierucci, 2006).

12. Na introdução da coletânea, Oro e Steil descrevem a reflexão proposta por Pierucci - a qual qualificam como "franca e provocadora" - como uma contribuição que, "a partir de Bourdieu, indaga sobre a objetividade científica de pesquisadores da religião que transitam e se encontram nesta fronteira porosa da ciência e da religião" (Oro e Steil, 1997, p. 20, grifos meus).

13. O materialismo, no caso, refere-se não a uma embocadura marxista - Pierucci se dizia ao mesmo tempo "weberiano e weberólogo" -, mas à intenção de mostrar, sempre, os interesses "mundanos" subjacentes às ações sociais no campo religioso (Mariano, 2013, p. 9; Bonato et al., 2016, pp. 25-26). 
da preguiça), que a participação religiosa incrementa a participação civil, enfim, que a religião produz subjetividades ativas (Pierucci, 1997, pp. 256-257).

A coisa complica ainda mais, diz Pierucci, "quando o autor se mete a estudar sua própria religião. O que, aliás, costuma acontecer. É muita illusio junto, diria Bourdieu” (Pierucci, 1999, p. 238). Na definição de Bourdieu, a “illusio é estar preso ao jogo, preso pelo jogo, acreditar que o jogo vale a pena ou, para dizê-lo de maneira mais simples, que vale a pena jogar" (Bourdieu, 2008a, p. 139). No caso em questão, dois jogos estariam sendo jogados ao mesmo tempo, existindo inclusive a tentação de se usar o capital obtido em um dos campos para obter lucros simbólicos no outro. Por exemplo, um sacerdote pode afirmar aos seus pares religiosos que detém maior conhecimento sobre o real sentido de certas escrituras sagradas valendo-se de suas credenciais obtidas como pesquisador; ao mesmo tempo, um pesquisador pode afirmar aos seus pares cientistas que compreende melhor o que está em jogo num culto, por ser ele mesmo membro daquela religião.

Essa espécie de contrabando de capitais possibilitado pela pertença aos dois campos, como já fora apontado, acarreta, na perspectiva bourdieusiana, uma série de dificuldades epistemológicas que precisam ser sanadas. "É justamente nisto que Bourdieu agora me vale", afirma Pierucci (1999, p. 274) ao tratar das críticas que devem ser feitas à dupla pertença. Afinal de contas, se as ciências sociais como um todo sofrem com a falta de prestígio no campo científico, "o obscuro e marginal ofício de sociólogo da religião" tem de enfrentar uma desconfiança dobrada devido à

[...] maciça presença entre nós, quem sabe excessiva ou quem sabe excessivamente tolerada, de "interesses religiosos" mobilizados não muito às claras e com escassa reflexividade por sociólogos amantíssimos do valor da religião, amorosíssimos para com as mais diversas formas de religiosidade e, ao mesmo tempo, desconfiados do que quer que se proponha ou se almeje como método científico, rigor científico, validade científica (Pierucci, 1999, p. 238).

O evidente escanteamento no campo científico que daí decorre, em vez de servir como sinal de alerta para uma mudança de rumos, argumenta Pierucci, estava sendo muitas das vezes romantizado, isto é, valorizado, como se fosse um traço distintivo das pesquisas sobre religião. E isso não seria novidade, uma irrupção recente no panorama acadêmico em nosso contexto nacional, mas dimensão constitutiva da área:

[...] as ciências sociais da religião no Brasil nunca foram, nem jamais chegaram a ser, uma área puramente acadêmica. Não o foram nos anos 1970, por onde começa este balanço, nem vieram a ser com o passar do tempo. Quase trinta anos se passaram e os sociólogos da religião no 
Brasil, assim como seus parceiros de empreitada, antropólogos em sua maioria mas também cientistas políticos e historiadores voltados para o estudo das religiões, continuamos todos a integrar ainda hoje uma área academicamente impura (Pierucci, 1999, p. 245).

Como é possível ver nos próprios editoriais da Religião \& Sociedade, a primeira revista de ciências sociais da religião no Brasil, fundada em 1977, muitos dos próprios pesquisadores à época se reconheciam e se dividiam entre os "puramente acadêmicos" e aqueles que estavam engajados em disputas ideológicas do campo religioso (Pierucci, 1999, p. 249). Essa composição é constatada também em outro balanço histórico da área, o de Solange Rodrigues (1997), que se vale do conceito bourdieusiano de campo para identificar, nos congressos da Anpocs ocorridos entre 1980-1997, "inúmeras interfaces entre o campo religioso, o campo político e o campo da produção de conhecimento" (Rodrigues, 1997, pp. 161-162).

Isso não seria tão problemático na medida em que se procurasse, reflexivamente, não praticar um jogo duplo. De que maneira? A solução, para Pierucci, novamente, já estaria dada por Bourdieu:

A resposta de Bourdieu vai ser: assumir bem-analisadamente a própria pertença religiosa, caso haja. Objetivá-la, torná-la objeto, submetê-la a um esforço de objetivação reflexiva sem complacência. Para o sociólogo da religião, esta é a única tomada de posição cientificamente consequente. Tem que assumir [...]. Bourdieu propõe portanto como única saída digna para os sociólogos que creem o avançar na direção de maior sociologização da própria prática sociológica (Pierucci, 1999, pp. 276-277).

Conforme apontava a sociologia da sociologia da religião que então fazia Pierucci, tal postura reflexiva não estaria sendo posta em prática. É à latente contaminação de interesses religiosos nas perspectivas (que deveriam e se propunham a ser) científicas que Pierucci atribuía, por exemplo, as constatações do "retorno do sagrado", ou "presságios benevolentes de ressurgência antes de mais nada da própria religião" do pesquisador em questão (Pierucci, 1999, p. 264). Diz ele:

[...] parte significativa do que se produz em sociologia da religião no Brasil, desde os anos 1970, faz o "elogio da religiáo" e aplaude com incontida euforia o "retorno do sagrado". Como saber se numa hora dessas é o cientista que fala ou não será o religioso, o crente, o místico praticando ventriloquia? (Pierucci, 1999, p. 276).

Tais diagnósticos efusivos, fervorosos, que ainda hoje são encontradiços e mal disfarçadamente celebrados na pena daqueles que têm "envolvimentos afetivo- 
-existenciais com o objeto de pesquisa" (Pierucci, 1999, p. 264), nada mais seriam, portanto, do que a tradução pseudoempírica daqueles tais interesses religiosos obnubilados.

\section{Reflexos da controvérsia: entre a catarse e os contrafogos}

A pretensão de, valendo-se de Bourdieu, "cutucar a onça com vara curta”, como Pierucci declaradamente procurou fazer em relação aos seus pares acadêmicos (Bonato et al., 2016, p. 25), teve (e continua tendo) repercussões das mais diversas. Em geral, as reações foram na direção de dissociar a crítica feita por Pierucci - que seria pertinente, mas excessiva - das advertências propostas por Bourdieu - as quais não se contestam explicitamente. No mais das vezes, porém, as respostas direcionadas a Pierucci contêm argumentações diametralmente opostas àquelas defendidas pelo sociólogo francês.

Para Breno Campos, por exemplo, "Pierucci tem razão ao criticar a produção sociológica de religiosos", porém ele teria extrapolado ao defender que "toda sociologia da religião feita por religiosos seja um elogio à religião” (Campos, 2007, pp. 122-124). Campos recorre ao próprio Bourdieu para defender seu ponto: “Quando Bourdieu faz a pergunta sobre a possibilidade de o sociólogo da religião religioso fazer sociologia da religião verdadeiramente científica, ele responde que é difícil, mas não impossível” (Idem, p. 124). Ainda segundo Campos, ao final de sua carreira, na fase de "pensamento maduro", o próprio Bourdieu teria passado a demonstrar certa "ambivalência”, isto é, "Bourdieu aceita ou passou a aceitar pelo menos o engajamento na última relação de passagem, ou seja, o retorno do conhecimento para a realidade" (Idem, p. 129).

Já para Marcelo Camurça, Pierucci estaria propondo "patrulhamento [...] nocivo ao pluralismo teórico-metodológico que caracteriza as ciências sociais" (Camurça, 2001, p. 12). Ainda, se a cobrança epistemológica feita aos cientistas sociais da religião fosse válida, ela "deveria ser estendida a pesquisadores com outras pertenças: uma militante feminista que faça uma antropologia de gênero, um ativista negro ou gay que realizem pesquisas sobre comportamento étnico e sexualidade" (Camurça, 2001, p. 10).

Camurça também cita outro grande nome das ciências sociais da religião no Brasil, Otávio Velho, defendendo que, como as fronteiras entre o campo religioso e as instâncias laicas da sociedade estão sendo cada vez mais borradas, a epistemologia científica clássica precisaria ser revista, dando maior relevância à experiência religiosa. Assim, enquanto "Pierucci reprova nos 'sociólogos religiosos' uma 'dificuldade séria de demarcar o contraste com a não ciência”, diz Camurça, "Velho vê como uma abertura o se 'deixar afetar pelo nativo'” (Camurça, 2001, p. 16). 
Outra linha de raciocínio adotada por Camurça consiste em afirmar que, "para além de envolvimentos afetivo-existenciais", também podem existir "preconceitos, ressentimentos, 'contas a ajustar"' com o próprio objeto de pesquisa (Camurça, 2001, p. 21). Haveria, assim, em contraposição à "boa vontade” dos pesquisadores religiosos que analisam a religião, uma "má vontade”, por parte de Pierucci, ao falar de seu objeto. Pierucci estaria, portanto, valendo-se de seu capital científico para, subliminarmente, criticar a religião.

É fogo contra fogo. Se Pierucci cita a advertência de Bourdieu sobre a existência de bispos sociólogos, Camurça cita outro exemplo, também de Bourdieu, no qual se fala de um ex-teólogo que se torna sociólogo buscando um "acerto de contas" com sua antiga identidade. A invertida é mordaz, uma vez que Pierucci foi um estudante de teologia que abandonou o seminário para se tornar sociólogo: "um ex-teólogo que se fez sociólogo pode, quando começa a estudar os teólogos [...], servir-se da sociologia para acertar suas contas de teólogo” (Bourdieu 1989, p. 51).

Já numa resposta mais recente às críticas de Pierucci, André Ricardo Souza exalta a importância das “oportunas provocações daquele sociólogo uspiano”, mas discorda de parte de seu diagnóstico, pois acha que "a proximidade com o objeto pesquisado, que é sem dúvida um desafio, pode significar e de fato costuma se constituir como uma vantagem a ser explorada" (Souza, 2015, p. 314). Souza reconhece a falta de prestígio da sociologia da religião no Brasil, mas atribui isso "muito mais ao forte traço ou viés materialista dos cientistas, em geral, do que à qualidade específica de trabalho dos sociólogos da religião, em particular" (Souza, 2015, p. 314). O problema estaria, portanto, fora e não dentro do campo de pesquisas da religião.

Dessa perspectiva, a declaração explícita da dupla pertença não se faz necessária. O que importa, isto sim, é a objetivação reflexiva, que não precisa ser pública: “o sociólogo da religião que é possuidor de alguma fé religiosa não tem obrigação ou dever, seja profissional ou moral, de assumir publicamente tal condição, mas, sim, $o$ direito de fazê-lo" (Souza, 2015, p. 312, grifos no original). Não se trata, dessa maneira, de negar o problema em potencial da dupla pertença, mas de discutir os modos de encarar essa questão. Afinal de contas, quando se deixam de lado as provocações e exageros, o que Pierucci faz, e faz bem, “é negritar que a religião dos sociólogos das religiões poderia ser mais reflexivamente problematizada (objetivação reflexiva $\dot{a}$ la Bourdieu), de modo a impedir que o processo de produção científica se tornasse escamoteado" (Rosas, 2018, p. 272).

Por fim, vale retomar a tese de Sonia Herrera (2004), Reconstrução do processo de formação e desenvolvimento da área de estudos da religião nas ciências sociais brasileiras, que também menciona a controvérsia instaurada por Pierucci a partir das leituras de Bourdieu. Esse trabalho é de grande valia aqui, pois Herrera realizou uma série 
de entrevistas com ícones que participaram ativamente da formação desse campo acadêmico.

Em uma das entrevistas, a de Maria José Rosado-Nunes, a pesquisadora reconhece, por exemplo, que: “a formação do campo de ciências da religião se dá no momento em que muita gente de igreja já não encontra espaço na igreja para trabalhar de uma maneira mais crítica; então, com muitas aspas, muitas aspas, uma contaminação, de fato eu acho que pode haver" (Herrera, 2004, pp. 296-297, grifos meus). Por isso, ainda nas palavras de Rosado-Nunes, seria imperativo aos pesquisadores "internos" apropriarem-se "de uma metodologia que lhes permita o afastamento necessário" (Herrera, 2004, p. 304). Assim, Rosado-Nunes (2017, p. 72) atesta como legítimos e pertinentes os apontamentos de Pierucci sobre os "riscos de perda da credibilidade científica da sociologia da religião provocados pelo enorme contingente [...] de interesses religiosos' disfarçadamente mobilizados por sociólogos que se mostram apegados demais ao valor da religião". Aliás, diz ela, "no campo de estudos de gênero" - que é sua área de expertise - "não é muito diferente" (Rosado-Nunes, 2017, p. 72).

Regina Novaes, por sua vez, também admite que "a questão da objetivação, para usar um termo da teoria de Bourdieu [...], é frontal”, porém, numa linha semelhante à de Camurça, afirma que "aqueles que estão contra a religião são tão religiosos como quem tem religião" (Herrera, 2004, pp. 297-299). É recorrente, dessa maneira, o apontamento de que não é possível assumir uma posição neutra nas ciências sociais e, por isso, a pertença religiosa seria tão problemática quanto a não pertença. Pedro Oliveira, por exemplo, afirma que o fato de "você estar no mundo acadêmico não o torna isento na hora de você fazer a pesquisa. A pesquisa do Pierucci sobre catolicismo no Brasil, por exemplo, é tão ideológica quanto a minha" (Herrera, 2004, p. 300). Em busca de uma explicação de por que o problema se apresenta no caso da pertença religiosa, mas não em outros (como gênero, raça etc.), Cecília Mariz afirma que isso se deve ao fato de que "as religiões propõem um saber alternativo, que compete com a ciência e que tem sido visto (e que foi de fato) como o opositor da ciência" (Herrera, 2004, p. 298).

Por fim, vale mencionar que, em seu balanço, Herrera constatou que, ao serem confrontados com a interrogação sobre a influência da identidade religiosa na pesquisa sobre religião, " $50 \%$ dos entrevistados associaram-na imediatamente a 'uma questão levantada por Pierucci', embora nem todos concordassem com a sua análise sobre a 'impureza' da área de estudos da religião" (Herrera, 2004, p. 298). Para esses pesquisadores, o ponto a ser enfatizado - como sintetiza a fala de Lísias Negrão ao também comentar essa controvérsia durante entrevista - era o de que, com as devidas objetificações, "não há um impedimento para que o pesquisador que tem uma certa religião [...] faça o estudo da religião, inclusive sua própria” (Herrera, 2004, p. 300). 
Negrão, aliás, foi outro renomado pesquisador que procurou responder às provocações de Pierucci, que era seu colega no Departamento de Sociologia da UsP. No artigo “Nem 'jardim encantado', nem 'clube dos intelectuais desencantados”, Negrão (2005, p. 33) queixa-se por ter sido "um dos agraciados com o (des)qualificativo de 'sociólogo religioso da religião"” com base em um texto no qual, na verdade, não haveria uma "insinuação relativa ao fim do paradigma da secularização" - por mais que, como ele mesmo reconhece, "a concisão do texto pudesse permitir tal interpretação” (Negrão, 2005, p. 33). Ao longo do artigo, porém, a questão do pertencimento religioso é deixada de lado e a controvérsia é deslocada para o plano teórico, no qual Negrão (2005) propunha outro entendimento para o conceito weberiano de "desencantamento do mundo", que, segundo ele, seria demasiadamente restrito na chave da "perda de sentido" proposta por Pierucci em sua tese de livre-docência.

Ou seja, apesar de postularem a inexistência de uma posição "neutra”, afirmando que o pesquisador (seja do fenômeno religioso, seja de qualquer outro) sempre parte de algum lugar do ponto de vista valorativo, os autores que repercutiram as críticas de Pierucci não estavam simplesmente abrindo mão de reivindicar um caráter objetivo para os seus respectivos trabalhos ou para as ciências sociais da religião como um todo. Pelo contrário, a pertinência científica das pesquisas feitas no Brasil sempre foi algo defendido quase unanimemente. A ânsia defensiva, porém, levou muitos a ignorarem que o cerne da crítica bourdieusiana mobilizada por Pierucci mirava os interesses religiosos ligados não só à execução e aos resultados da pesquisa - que, por exemplo, poderiam legitimar a posição "superior" de um pesquisador em uma controvérsia na qual ele também estava envolvido no campo religioso -, mas também aos pressupostos teóricos dos quais elas partiam.

\section{A desmitificação bourdieusiana do homo religiosus: um alicerce à compreensão da dinâmica religiosa contemporânea}

Bourdieu identifica, na divisão do trabalho religioso, a existência de produtores (os profetas, que representam a inovação, o extraordinário) e de reprodutores de visões de mundo (a igreja e o corpo sacerdotal, que representam o cotidiano, o ordinário) (2011b, p. 89). Do ponto de vista de sua economia dos bens simbólicos, essas diferentes figuras, às quais se deve acrescentar a do feiticeiro, encontram-se em permanente concorrência estrutural num campo específico, o campo religioso. Nele, a igreja e seu corpo sacerdotal são como grandes empresas tradicionais, enquanto o profeta e o feiticeiro são empreendedores independentes, mas com ambições, origens sociais e formações diversas. O profeta tem a pretensão do exercício legítimo do poder religioso e busca recalcar seu interesse temporal. Já o feiticeiro se submete de forma 
escancarada ao interesse material, assumindo "explicitamente seu papel na relação vendedor/cliente que constitui a verdade objetiva de toda relação entre especialistas religiosos e leigos" (Bourdieu, 2011a, p. 61).

A verdade da empresa religiosa é a de ter duas verdades: a verdade econômica e a verdade religiosa, que a recusa. Logo, para descrever cada prática [...], seria preciso utilizar duas palavras, sobrepostas como em um acorde musical: apostolado/marketing, fiéis/clientela, serviço sagrado/trabalho assalariado etc. (Bourdieu, 2008b, p. 185).

O postulado de uma lógica econômica subjacente à dinâmica do campo religioso tem sido cada vez mais explorado, sem no entanto haver um diálogo com a obra bourdieusiana, pelo assim chamado "novo paradigma" da sociologia da religião - ou "teoria econômica da religião", teoria da "economia religiosa", "paradigma da escolha racional da religião" e afins (Frigerio, 2008; Mariano, 2008). Tal paradigma, vale ressaltar, também não pode ser considerado como simples desdobramento dos postulados de Peter Berger (1985) ${ }^{14}$, que elencava o avanço do pluralismo e a privatização da fé como fatores que submeteriam as religiões no mundo moderno (secularizado) à lógica do mercado. Para Berger (1985), em sociedades antes cobertas por um "dossel sagrado", a mercantilização da fé, em oposição às identidades religiosas tradicional e tranquilamente herdadas, tendia a minar - e não a fortalecer - a vitalidade do fenômeno religioso.

Já "para os autores norte-americanos o fato de que os distintos segmentos do mercado possam encontrar religiões com que se identificar leva a mais e melhor religião, não a seu empobrecimento" (Frigerio, 2008, p. 26). Dois dos expoentes do “novo paradigma”, Stark e Bainbridge (1985), por exemplo, afirmam que em mercados religiosos desregulados, nos quais não existe um impedimento à proliferação dos cultos por parte do Estado, há uma tendência de surgimento contínuo de novas "empresas de salvação" cada vez mais eficientes e mais antenadas com as demandas sempre renovadas dos indivíduos. É por isso que, segundo Iannaccone (1997), os índices de religiosidade medidos nos surveys tendem a ser mais altos em países com maior pluralismo religioso Dessa perspectiva, portanto, o pluralismo e a concorrência que ele impõe seriam, acima de tudo, trunfos, molas propulsoras que fariam a oferta religiosa prosperar em uma dada sociedade, e não o contrário.

14. As teorias defendidas por Berger (1985) em $O$ dossel sagrado sofreram uma série de reviravoltas nas décadas seguintes, passando desde a defesa do paradigma da "dessecularização" (Berger, 2000), até a proposta de um novo "paradigma da religião numa época pluralista” (Berger, [2014] 2017) um pouco antes de sua morte, que ocorreria em 2017. 
Isso posto, vale apontar que Bourdieu não adota "a mesma radicalidade economicista” que está presente nessas teorias (Mariano, 2008, p. 47). Sua concepção de "interesse" leva em conta muito mais do que o mero cálculo reflexivo de custo-benefício (Raud, 2007, p. 222). O ponto maior de dissonância da teoria bourdieusiana em relação aos autores do "novo paradigma", todavia, encontra-se no postulado por eles defendido - às vezes implícita, às vezes explicitamente - de que a demanda pelos bens religiosos é uma "demanda geral e inexaurível" (Stark, 1999, p. 265). Na mesma linha, William Swatos e Kevin Christiano chegam a dizer que "as respostas religiosas sempre terão um lugar na experiência humana" (1999, p. 217).

Da perspectiva bourdieusiana, contudo, é impossível aceitar a religiosidade como dado natural. Ela deve ser tratada como algo socialmente inculcado, que depende do "trabalho religioso" (Bourdieu, 2011b). Afinal de contas, se a religião fosse independente da cultura, não teria sentido estudá-la sociologicamente. A teoria econômica da religião pode até estar correta ao postular que a concorrência desregulada das religiões amplia e diversifica a oferta dos "bens de salvação" (Stark e Bainbridge, 1985, p. 435). Mas, de um ponto de vista bourdieusiano, isso ocorre não porque a demanda por religião é uma constante imutável, e sim porque, na medida em que a concorrência se intensifica, os líderes religiosos não podem mais ficar de braços cruzados, preocupados apenas em gerir a pertença a uma religião tradicionalmente herdada e, por isso, naturalizada.

É a partir dessa concorrência e das recorrentes inovações que surgem da disputa pelos fiéis, afirma Pierucci mais uma vez na esteira de Bourdieu, que o produto "religião" acaba sendo "flexibilizado" junto com as próprias fronteiras do campo religioso, cada vez mais borradas - dissolvidas, diria Bourdieu (1990c) - nas mãos e na fala dos "agentes profano-religiosos das igrejas-empresas - grandes, pequenas e microempresas de serviços religiosos - que oferecem respostas efetivas à demanda efetiva dos adeptos/ clientes por resultados efetivos" (Pierucci, 1999, p. 273). Isso abre margem a uma grande diversificação da atividade religiosa, oferecida agora em

[...] escolas, rádios, emissoras de televisão, editoras, livrarias, jornais e revistas, lojas de disco e vídeo, produção e comercialização de objetos religiosos e souvenirs, instituições financeiras, instituições de saúde, serviços de terapia religiosa, de aconselhamento psicoterápico, de atendimento paramédico, creches, orfanatos, hospitais, estruturas imobiliárias, construtoras, prédios de apartamentos e de escritórios, propriedades fundiárias de todo tipo e tamanho, ONGs, lobbies, empresas de marketing etc., muitas delas, atividades econômicas sob o guarda-chuva da isenção fiscal por se tratar de organizações religiosas (Pierucci, 1999, p. 274). 
Nesse cenário, saem perdendo as religiões mais tradicionais, que oferecem bens de salvação muito intangíveis, no além. Seu declínio é constatado de forma quase unânime na literatura acadêmica nacional e internacional (Bruce, 2016; Casanova, 2007; Heelas, 2006; Hervieu-Léger, 1997, 2006, 2015; Pierucci, 2004; Prandi e Santos, 2015). Por outro lado, ganham aquelas denominações, como as evangélicas pentecostais, que dizem poder oferecer Deus já, agora, sem que se precise mudar radicalmente de vida, de gostos e costumes (Prandi, Santos E Bonato, 2019; Mariano, 1999). Isso só ocorre porque, no campo religioso brasileiro contemporâneo, pode-se experimentar à vontade, mudar desta para aquela denominação, converter-se sem frequentar o culto, ou frequentar diversos cultos sem se converter a nenhum deles, tudo isso que, há não muito tempo, geraria no mínimo um escândalo social. Hoje, não mais. Hoje vale o lema: "para um problema novo, uma religião nova" (Prandi e Santos, 2017, p. 209).

De uma perspectiva sociológica menos unívoca, é possível constatar, portanto, que tal dinamismo do campo religioso tem como condição o deslocamento da religião para cada vez mais longe dos centros estruturantes da vida social. Assim, de que um contexto qualquer seja "mais religioso", não se pode deduzir, necessariamente, que seja "menos secularizado" (Casanova, 2007, p. 6, tradução minha).

\footnotetext{
"Devagar com o andor", diria Flávio Pierucci aos que se lançam no campo empírico deslumbrados, sem a devida orientação teórica, ansiosos em encontrar encantos que, magicamente, com o toque da varinha da boa vontade religiosa, acabam transformando a efervescência de formigueiros em erupções vulcânicas (Bonato et al., 2016, p. 31).
}

Ora, é justamente para se opor à ideia de que a diversificação da oferta religiosa seja evidência de dessecularização que Pierucci, "seguindo Weber e Bourdieu, defendia que 'ninguém nasce religioso', mas se torna religioso" (Mariano, 2013, p. 12). Nas palavras do próprio Pierucci:

[...] o homem não nasce religioso, ele se torna. No nace, se hace [...]. O homo religiosus é algo que se produz, aprendemos com Weber e reaprendemos com Bourdieu. Ele é produzido por profissionais da religião [...]. [Por isso, deve-se] evitar, como um princípio de método - método científico e também método anticoncepcional - conceber o chamado "interesse religioso" como sendo especificamente religioso já no ponto de partida, como sendo prima facie religioso. Evitar proceder como se o interesse religioso não fosse um produto do trabalho religioso [...]. Pierre Bourdieu estava muito atento a essa boa ideia de Max Weber (Pierucci, 2003, pp. 81-83, grifos no original). 
Em suma, a desnaturalização da demanda religiosa é um passo fundamental para se compreender o diagnóstico de que, apesar da aparência de uma religiosidade pulsante e viva como nunca entre os indivíduos, a religião não tem mais o papel socialmente relevante de outrora, seja no Brasil de hoje ou nos demais contextos de "modernidade religiosa", isto é, contextos marcados por um mercado religioso desregulamentado. Tomar como ponto de partida esse dessacralizante postulado bourdieusiano é tão fundamental para o realinhamento das ciências sociais da religião hoje como foi, em décadas passadas, a convocação para refletir e objetivar os desvios que a dupla pertença (ser fiel, ser cientista) poderia gerar nas análises dos fenômenos religiosos. Tal como antes, portanto, um pouco mais de Bourdieu ainda faria muito bem a todos nós.

\section{Referências Bibliográficas}

Arribas, C. G. (2012), “Pode Bourdieu contribuir para os estudos em ciências da religião?”. Numen: Revista de Estudos e Pesquisa da Religião, 15 (2): 483-513.

Beckford, J. A. (2008), Social theory and religion. Cambridge, University Press.

Berger, P. (1985), O dossel sagrado. São Paulo, Paulus.

Berger, P. (2000), “A dessecularização do mundo: uma visão global”. Religião e Sociedade, 21

(1): 9-24. Disponível em http://www.uel.br/laboratorios/religiosidade/pages/arquivos/ dessecularizacaoLERR.pdf.

Berger, P. ([2014] 2017), Os múltiplos altares da modernidade. Petrópolis, Vozes.

Bonato, M. et al. (2016), "Secularização em Antônio Flávio Pierucci - da contemporânea serventia de continuarmos acessando aquele velho sentido”. Século XXI, 6 (1): 11-43.

Bortoluci, J. H.; Jackson, L. C. \& Filho, F. P. (2015), “Contemporâneo clássico: a recepção de Pierre Bourdieu no Brasil”. Lua Nova, 94: 217-54.

Bourdieu, P. (1983), “Uma ciência que perturba”. In: Bourdieu, P. Questões de sociologia. Rio de Janeiro, Marco Zero, pp. 16-29.

Bourdieu, P. (1989), "Introdução a uma sociologia reflexiva”. In: Bourdieu, P. O poder simbólico. Rio de Janeiro, Bertrand, pp. 17-58.

Bourdieu, P. (1990a), "Fieldwork in philosophy”. In: Bourdieu, P. Coisas ditas. São Paulo, Brasiliense, pp. 15-48.

Bourdieu, P. (1990b), “Sociólogos da crença e crenças de sociólogos”. In: Bourdieu, P. Coisas ditas. São Paulo, Brasiliense, pp. 108-13.

Bourdieu, P. (1990c), “A dissolução do religioso". In: Bourdieu, P. Coisas ditas. São Paulo, Brasiliense, pp. 119-125.

Bourdieu, P. (1990d), “Da regra às estratégias”. In: Bourdieu, P. Coisas ditas. São Paulo, Brasiliense, pp. 77-95. 
Bourdieu, P. (1990e), "Pontos de referência”. In: Bourdieu, P. Coisas ditas. São Paulo, Brasiliense, pp. 49-73.

Bourdieu, P. (2001), Meditaçôes pascalianas. Rio de Janeiro, Bertrand Brasil.

Bourdieu, P. (2002), A dominação masculina. Rio de Janeiro, Bertrand Brasil.

Bourdieu, P. (2007), Ofício de sociólogo. Petrópolis, Vozes.

Bourdieu, P. (2008a), “É possível um ato desinteressado?”. In: Bourdieu, P. Razões práticas. Campinas, Papirus, pp. 137-156.

Bourdieu, P. (2008b), "A economia dos bens simbólicos”. In: Bourdieu, P. Razões práticas. Campinas, Papirus, pp. 157-198.

Bourdieu, P. (2011a), “Gênese e estrutura do campo religioso” In: Bourdieu, P. A economia das trocas simbólicas. São Paulo, Perspectiva, pp. 27-78.

Bourdieu, P. (2011b), “Uma interpretação da teoria da religião de Max Weber”. In: Bourdieu, P. A economia das trocas simbólicas, São Paulo, Perspectiva, pp. 79-98.

Bruce, S. (2016), “Secularização e a impotência da religião individualizada”. Religião \& Sociedade, 36 (1): 178-190.

Campos, B. M. (2007), "Sociologia religiosa da religião". Ciências da Religião: História e Sociedade, 5 (5): 111-33.

Camurça, M. A. (2001), “Da 'Boa' e da 'má vontade' para com a religião nos cientistas sociais da religião brasileiros”. Religião \& Sociedade, 21 (1): 67-86.

Casanova, J. (2007), “Reconsiderar la secularización”. Revista Académica de Relaciones Internacionales, 7: 1-20.

Dianteill, E. (2003), “Pierre Bourdieu e a religião”. Revista de Ciências Sociais, 34 (2): 30-42.

Frigerio, A. (2008), “O paradigma da escolha racional”. Tempo Social, 20 (2): 17-39.

Heelas, Paul. (2006). "Challenging Secularization Theory”. The Hedgehog Review - After Secularization, 8, 1-2: 46-58.

Herrera, S. E. R. (2004), Reconstrução do processo de formação e desenvolvimento da área de estudos da religião nas ciências sociais brasileiras. Porto Alegre, tese de doutorado, Universidade Federal do Rio Grande do Sul.

Hervieu-LÉger, D. (1997), "Representam os surtos emocionais contemporâneos o fim da secularização ou o fim da religião?” Religião e Sociedade, 18 (1): 31-47.

Hervieu-Léger, D. (2006), "In search of certainties". The Hedgehog Review - After Secularization, 8 (1-2): 59-68.

Hervieu-Léger, D. (2015), O peregrino e o convertido. Petrópolis, Vozes.

IANNACCONE, L. (1997), "Rational choice: framework for the scientific study of religion”. In:

Young, A. (org.), Rational choice theory and religion. Nova York, Routledge, pp. 25-44.

Mariano, R. (1999), Neopentecostais. São Paulo, Loyola.

Mariano, R. (2008), “Usos e limites da teoria da escolha racional da religião”. Tempo social, 20 (2): 41-66. 
Mariano, R. (2013), “Antônio Flávio Pierucci: sociólogo materialista da religião”. RBCS, 28 (81): 7-16.

Miceli, S. (1999), O que ler na ciência social brasileira (1970-1995). Vol. II: Sociologia. São Paulo, Sumaré/Anpocs, pp. 237-287.

Negrão, L. (2005), “Nem 'jardim encantado', nem 'clube dos intelectuais desencantados”. RBCS, 20 (59): 23-36.

Rosado-Nunes, M. J. (2017), "Feminismo, gênero e religião". Estudos de Religião, 31 (2): 65-76.

Oro, A. \& Steil, C. (1997), Globalização e religião. Petrópolis, Vozes.

Ortiz, R. (2013), “Nota sobre a recepção de Pierre Bourdieu no Brasil”. Sociologia \& Antropologia, 3 (5): 81-90.

Pierucci, A. F. (1997), “Interesses religiosos dos sociólogos da religião”. In: Oro, A. \& STEIL, C. (orgs.). Globalização e religião. Petrópolis, Vozes, pp. 249-62.

Pierucci, A. F. (1999), “Sociologia da religião: área impuramente acadêmica”. In: Sergio Miceli (org.). O que ler na ciência social brasileira (1970-1995). Vol. II: Sociologia. São Paulo, Sumaré/Anpocs, pp. 237-287.

Pierucci, A. F. (2003), O desencantamento do mundo. São Paulo, Editora 34.

Pierucci, A. F. (2004), “Bye, Brasil”. Estudos Avançados, 18 (52): 17-28.

Pierucci, A. F. (2006). Memorial para concurso de professor titular de Sociologia da USP. São Paulo, Faculdade de Filosofia, Letras e Ciências Humanas da Universidade de São Paulo, FFLCH-USP (mimeo).

Prandi, R. \& Santos, R. W. (2015), "Mudança religiosa na sociedade secularizada”. Contemporânea, 5 (2): 351-79.

Prandi, R. \& Santos, R. W. (2017), “Quem tem medo da bancada evangélica?” Tempo Social, 29 (2): 187-213.

Prandi, R.; Santos, R. W. \& Bonato, M. (2019), "Igrejas evangélicas como máquinas eleitorais no Brasil". Revista USP, 200, 1: 43-60.

Raud, C. (2007), “Bourdieu e a nova sociologia econômica”. Tempo Social, 19 (2): 203-32.

Rodrigues, S. (1997), “Trabalhos apresentados no 'GT Religião e Sociedade’ da Anpocs (1980-1997)". Religião \& Sociedade, 18 (2): 157-79.

Rosas, N. (2018), Sociologia da religião: comentário a um balanço sobre a produção do conhecimento. Mediações, 23 (1): 263-290.

SouzA, A. R. (2015), "A livre religiosidade e a compulsória ciência do sociólogo da religião". Contemporânea, 5 (2): 309-325.

STARK, R. (1999), “Micro foundations of religion”, Sociological Theory, 17 (3): 264-289.

Stark, R. \& BAinbridge, W. S. (1985), The Future of Religion. Berkeley, University of California.

Swatos Jr., W. \& Christiano, K. (1999), “Secularization Theory”. Sociology of Religion, 60 (3): 209-228. 
Weber, M. ([1920] 1996), “Introdução”. In: Weber, M. A ética protestante e o espírito do capitalismo. Lisboa, Presença, pp. 11-24.

Weber, M. ([1922] 2004), “Sociologia da religião”. In: Weber, M. Economia e Sociedade, vol. 1. São Paulo, Editora Universidade de Brasília, pp. 279-418.

Weber, M. ([1895] 2014a), “O Estado-nação e a política econômica”. In. Weber, M. Escritos politicos. São Paulo, Martins Fontes, pp. 3-36.

Weber, M. ([1920] 2014b), A “ética" protestante e o "espírito" do capitalismo. São Paulo, Companhia das Letras.

\section{Resumo}

A dessacralização das ciências sociais da religião no Brasil nas trilhas de Weber, Bourdieu e Pierucci $\mathrm{O}$ artigo procura reconstruir a repercussão da crítica bourdieusiana à produção sociológica sobre os fenômenos religiosos, a qual aponta para a dificuldade que perpassa o envolvimento do pesquisador com seu objeto de estudo. Na sociologia da religião praticada no Brasil, tal crítica suscitou (e ainda suscita) intenso debate, sobretudo após ter sido mobilizada com intenção declaradamente polemista por um dos ícones dessa área no contexto nacional, Antônio Flávio Pierucci. A intenção aqui é não apenas analisar como a discussão se desdobrou e os argumentos mobilizados ao longo da controvérsia, mas também reafirmar a importância dos postulados de Bourdieu, defendendo a pertinência de seu uso na interpretação da dinâmica religiosa em nosso país.

Palavras-chave: Sociologia da religião no Brasil; Pierre Bourdieu; Antônio Flávio Pierucci; Neutralidade axiológica; Objetividade científica.

\section{Abstract}

The desacralization of the Social Sciences of Religion in Brazil in the footsteps of Weber, Bourdieu and Pierucci

The article aims to reconstruct the repercussion of the bourdieusian critique to the sociological analysis of the religious phenomena, which points to the difficulty that permeates the researcher 's involvement with his object of study. In the Brazilian Sociology of Religion, such criticism has aroused (and still raise) intense debate, especially after being mobilized with avowed polemic intention by Antônio Flávio Pierucci, one of the main researchers of this field in the national context. The purpose here is not only to analyze how the discussion unfolded and the arguments mobilized throughout the controversy, but also to reaffirm the importance of Bourdieu's postulates, defending the pertinence of its use in the interpretation of the religious dynamics in our country.

Keywords: Brazilian Sociology of religion; Pierre Bourdieu; Antônio Flávio Pierucci; Axiological neutrality; Scientific objectivity. 
Texto recebido em 12/6/2019 e aprovado em 20/9/2019.

DOI: $10.11606 / 0103-2070 . t s .2020 .158831$.

Renan William dos Santos é doutorando no Programa de Pós-graduação em Sociologia da Universidade de São Paulo, com apoio da Fundação de Amparo à Pesquisa do Estado de São Paulo, processo n.2017/24842-1. E-mail: renan16@outlook.com.

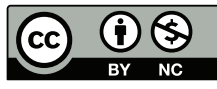

